Ethiopian Journal of Environmental Studies and Management Vol. 4 No.4 2011

\title{
GEOLOGY AND ENVIRONMENTAL IMPACT ASSESSMENT AND BENEFIT OF GRANITIC ROCKS OF MINNA AREA, NORTHWESTERN NIGERIA. \\ Alabi, A. A. \\ DOI: http://dx.doi.org/10.4314/ejesm.v4i4.5
}

Received November $23^{\text {rd }} 2011$; accepted December $5^{\text {th }} 2011$

\begin{abstract}
Nigeria basement complex has shown that the older granites are high level intrusions emplaced by stoping and diapiric process and include spectrum of rocks varying in composition from tonalite through granodiorite to granite. The intense regional deformation which accompanied and preceded the emplacement of the older granite result in it pronounced and wide spread northeast trend. The granites termed older granites in Nigeria have been dated severally at 500-750 million years. Minna is situated in the central part of the Nigeria basement complex surrounded by rugged terrain of granitic rocks, this necessitates the geological and impact assessment of the granitic rock in Minna. Field study reveals eight granitic masses which occur as Paiko and Minna batholiths and as continuous ridge in north-south direction of about $18 \mathrm{kms}$ and average height of 350 meters above sea level. In hand specimen, the granitic rocks vary from medium, porphyritic to coarse variety from light colored to medium dark colored.
\end{abstract}

Key Words: Geology, Environmental impact, Assessment, Benefit and Granitic Rocks.

\section{Introduction}

The Older Granite of Nigeria includes a wide spectrum of rocks varying in composition from tonalite through granodiorite to granite, syenite and charnockite rocks (Trustwell et. al, 1963). The granitoids have been emplaced into both the migmatite-gneiss complex and the schist belts, and they occur in all parts of Nigeria (Ajibade, 1982). Recent work in different parts of the Nigerian basement complex has shown that the older granites are high level intrusions emplaced by stoping and diapiric process (Fitches et. al, 1985). The marked generally north-south linear aggregation of many of the large batholiths of the basement suggests that they may be related to deep-seated pre-existing plutonic episode controlled by major deep mantle structure (Ogezi, 1977a).The intense regional deformation which accompanied and preceded the emplacement of the older granite resulted in the pronounced and wide spread of N-S trend.The granites termed the older granites in Nigeria have been dated severally at 500-750 ma (Van Breem et. al 1977, Rahaman et. al, 1983 and Kroner 1998).

Granitic magma is commonly associated with several tectonic stages during evolution, and their structure, texture, and mineralogy composition can be of benefit and environmental impact (Pearce et.al. 1984, Pitcher 1983, 1989, Whalen et al 1987, Frost et. al, 1999).

Department of geology, Federal University of

Technology Minna, Nigeria.

Email:kola_rock@yahoo.com
Minna is situated in the central part of Nigeria basement complex, surrounded by rugged terrain of granitic rocks. There is need to examine the origin, attributes and benefits of these rocks in the area.

\section{Methodology}

\section{Study Area}

Minna is located between longitude $6^{0} 25^{\prime} \mathrm{E}$ and $6^{0} 45^{\prime} \mathrm{E}$ and latitude $9^{0} 24^{\prime} \mathrm{N}$ and $9^{0} 48^{\prime} \mathrm{N}$, it occupy the central portion of the Nigerian basement complex. The Minna area comprises of metasedimentary and meta-igneous rocks which have undergone polyphase deformation and metamorphism. These rocks have been intruded by granitic rocks of Pan-African age.

Five lithostratigraphic units have been recognized in Minna area (Fig. 1). The schist which occur as a flat laying narrow southwest-northeast belt at the central part of Minna with small quartzite ridge parallel to it, the gneiss occur as a small suites at the northern and southern part of the area forming a contact with the granite. Feldspathic rich pegmatite is bounded to the east, with average width of 65meters and 100 meters long, the pegmatite host tourmaline. Granitic rocks dominate the rock types in the area and vary in texture and composition. Detailed geological mapping of the area was carried out on a map scale 1: 25,000 using geological compass clinometers, hammer and GPS. The mapping exercise involved description, 


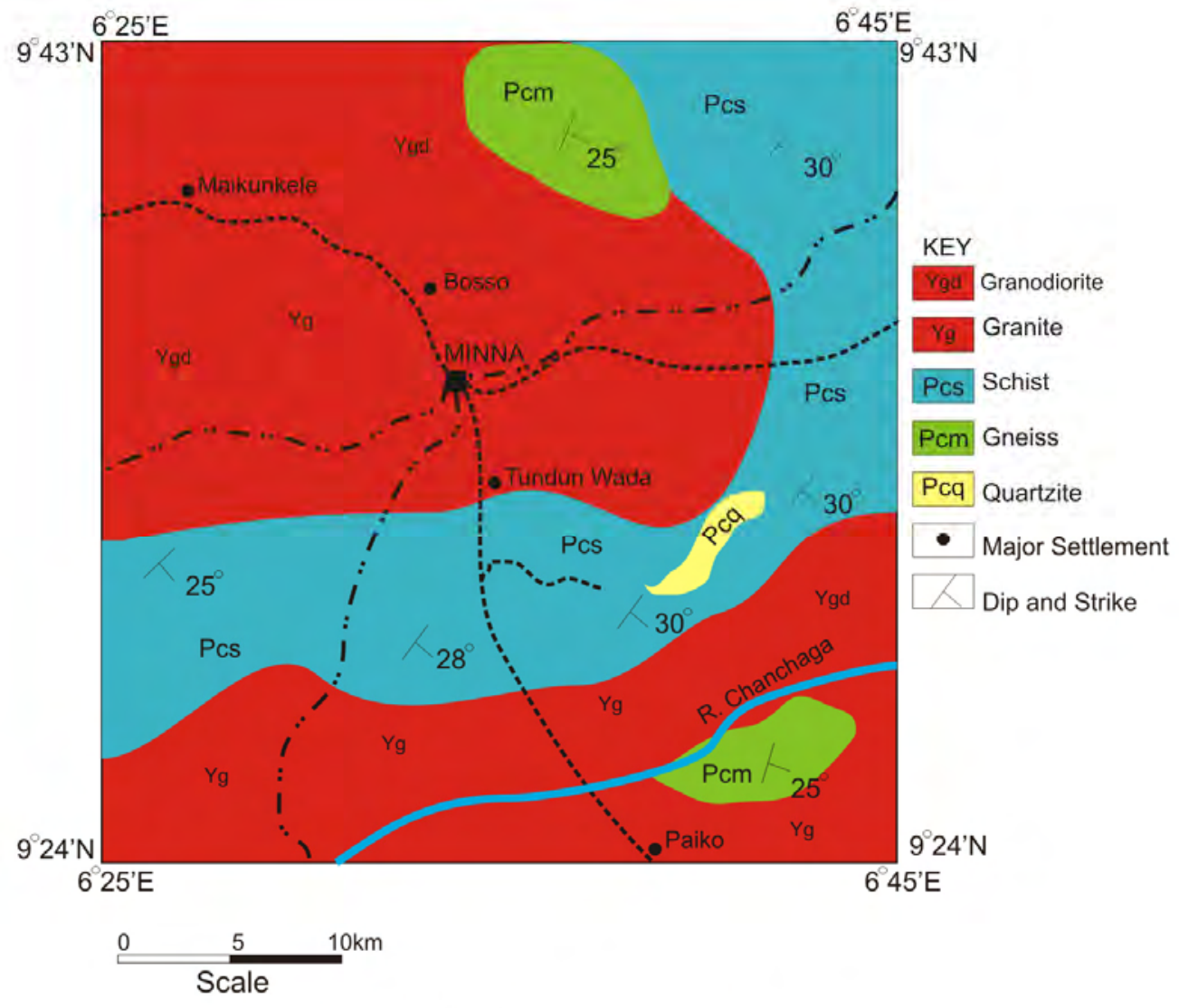

FIG 1: GEOLOGICAL MAP OF MINNAAREA

measurement and sampling of the outcrops. Fresh samples of outcrops were collected from different locations and were studied in hand specimen. Meso-structures and the attributes of the outcrops were measured and described in the field.

The rock thin sections were prepared in the Geology Department Federal University of Technology, Minna. Four fresh rock samples were cut into thin section using rock cutting and lapping machine. The thin sections were studied under plane and cross polarized light microscope and photomicrographs of the samples were produced. The optical properties of the minerals present in the thin section of each sample were used to determine the relative abundance of major, minor and accessory minerals.

\section{Results}

In the field eight large granitic masses occur as batholiths and continuous uninterrupted ridge in north-east direction of about $18 \mathrm{~km}$ long, average width of $1.5 \mathrm{~km}$ and an average height of 35 meters above sea level. Five striking features of the older granite occur as batholiths, that is prominent rising sharply above their surrounding plains, such granitic batholiths occur as Paiko and Minna batholiths. The Paiko batholith is almost circular with a maximum diameter of $2000 \mathrm{~m}$ and $430 \mathrm{~m}$ high. Other outcrops are flat lying. In the field, meso-structures of non-penetrating cross joints and faults of which most are quartz filled was examined in most of the outcrops, the quartz vein is usually between $1 \mathrm{~cm}-35 \mathrm{~cm}$ wide.

Foliation is present near the top of the north granitic ridge. Exfoliation is common on the outcrops. In hand specimen, the granitic rocks vary from medium, porphyritic to coarse variety and ranges from light colored to medium dark colored.

The porphyritic granite contains phenocryst of plagioclase in ground mass of quartz, muscovite, orthoclase and minor hornblend. Muscovite acquired elongated structure probably as a result of shearing. Plagioclase granular structure is as a result of slow cooling during the formation of the rock. Under plane polarize light, quartz, plagioclase, orthoclase and muscovite are colorless, while under cross polar quartz color vary from grey to cream, plagioclase yellow, hornblend blue, orthoclase white and muscovite green. These colors 
are at extinct at rotation angles of $45^{\circ}, 30^{\circ}, 15^{\circ}$ and $90^{\circ}$ respectively (Figure 1a,1b. 2a,2b.3a,3b). The microcline and biotite composition in granodiorite is responsible for the dark color. In all the granites, twining axis is normal to the compositional plane in plagioclase and inversion twining in plagioclase.

Visual relative proportions of the minerals present in the thin section show considerable variation (plate $1,2 \& 3$ ). Thus quartz varies between 23 and 30 percent, orthoclase between 17 and 24 percent, plagioclase between 37-52 percent, biotite between 04-13 percent, muscovite and hornblende are about 2 percent. Accessory minerals are present in small amount (Table 1, $2 \& 3$ )

\section{Discussion}

Mineralogical composition of analyzed granitic rock samples, indicate variation grading from granodiorite to granite which represents separate intrusions. It seems that the granite was intruded as a granodiorite and latter metasomatism of which the bulk composition of the rock was transformed to granite. The diapiric nature of the magma that crystallized to form granite, results in the high level rugged batholiths and ridges in the study area. Mineralogy composition comparison of Minna granite and granodiorite with adjacent Madaka granite and Tegina granodiorite show similarity in mineralogical composition( Table 4 and 5). This indicates similarity in their mode of formation.

The granitic ridge is elongated parallel to the regional structural trend, the ridge and the batholiths are poorly vegetated and hence expose their area surface. The inhabitant of Minna area take advantage of the thin overburden which ranges from few meters to about 3 meters (Unuevho, 2009) for foundation construction, most of the houses are built on and along the ridge and the heat radiation from the ridge and batholiths are responsible for the local increase in temperature of the area, the steep nature of the ridge and batholiths promote run-off that causes flooding during the rainy season. The striking features of these outcrops occupy about 35 percent of the northeast, therefore restricts land use and urban development to the southwest. The nonpenetrating cross joints and fairly weathered nature of the flat lying outcrop make it a poor aquifer and hence there is 85 percent failed boreholes in the area. Due to the availability and properties of the granitic outcrops, there are quarries in north and northeast which is the source of rock aggregates and powder for constructions.

The dominant rock types in the area are of monotonous pattern of medium to coarse grained granodiorite and granite. Their orogenic evolution is of two generations, the early formed granodiorite and late formed high level granite. The striking features of the Minna granitic rocks and its geological structure is of less benefit but rather of great impact to the inhabitant of the area.

\section{References}

Ajibade, A.C., (1982), The Origin of the Older Granite of Nigeria: Some evidence from the Zungeru region. Nigeria Jour. Of Min. and Geol., 19, 223-230.

Fitches, W. R., Ajibade, A. C. , Egbuniwe, I. G., Holt, R. W. , and Wright, J. B.( 1985), Late Proterozoic Schist belts and Plutonism in NW Nigeria. Jour. Of Geol. Soc. London, 142, pp. 319337.

Frost, C.D, Frost, B.R., Chamberlian, K.R. and Edwards, B.R (1999), Petro genesis of the $1.43 \mathrm{Ga}$ Shermanbatholith, S.E. Wyoming: A reduced rapakivi-rype anorogenic granite. J. Petrol, 40, pp. 1771-1802.

Kroner, A. (1984), Fold Belt and plate Tectonics in the Precambrian. Proceedings of the $27^{\text {th }}$ International Geological Congress, Precambrian Geology. 5, 247- 280.

Ogezi, A. E. O., (1977), Geochemistry and Geochronology of Basement Rocks from NW Nigeria. $19^{\text {th }}$ Annual Report. Res. Inst. Africa. Geology, Uni. Leads, pp. 52-53.

Pitcher, W.S. (1983), Granite type and tectonic environment. In :Hsu, K. (ed) Mountain Building Processes, Academic Press, London. Pp. 19-40. Pearce, J.A., Harris, N.B.W., Tindle, A.G. (1984), Trace element discrimination diagram for the tectonic interpretation of granitic rocks. J. Petrol., 25, 956-983.

Rahaman, M. A., Emofureta, W. O. and Cean Vacheta, M.,( 198), The Potassic of the granites of the Igbeti area: Futher Evidence of the Polycyclic Evolution of the pan-Africa Belt in Southwestern Nigeria, Proc. Res. 22, pp. 25-92.

Truswell , J.F., Cope, R.N. (1963). The geology of parts of Niger and Zaria provinces, Northern Nigeria. Bulletin No. 29. Published by Geological Survey of Nigeria. pp.17-22. 
Unuevho, C. I., (2009):- Graphic determination of depth to fresh crystalline basement from schlumberger sounding curves: Applicability in Minna, Niger State, Nigeria .Jour. of Sci. Tech. and Maths Education. Pp. 191-210.

Van Breemar, O., Pigeon, R.T. and Bowden, P., (1977):- Age and Isotopic studies of some Pan-
Africa granite from central Nigeria. Res., 4, 307319.

Whalen, J.B., Currie, K.L. and Chappel, B.W. (1987):- Atype granite: Geochemical characteristics and petrogenesis. Cont. Min. Petrol., 95:407-419.

Plate 1 Photomicrograph of granite (a) under crossed polar and (b) under plane polar (Mg.10X)

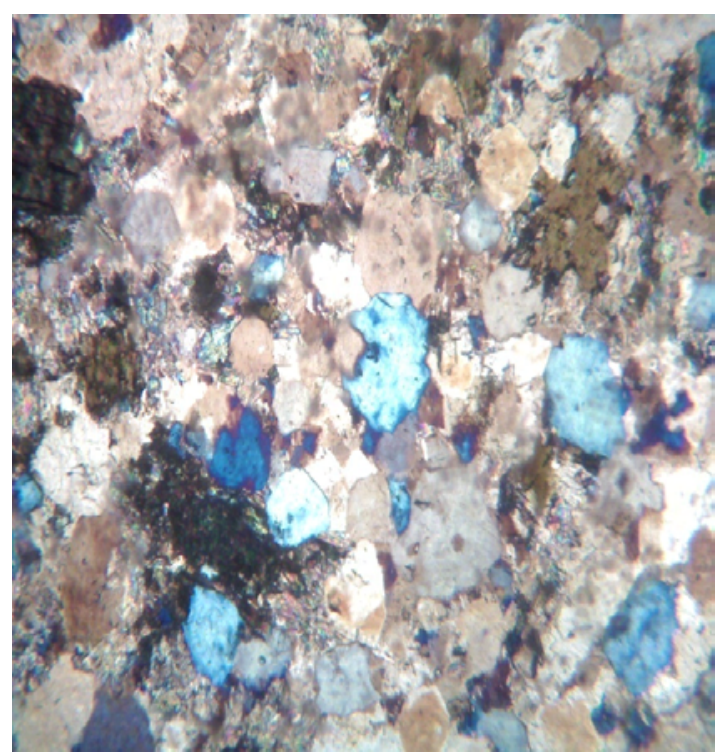

(a)

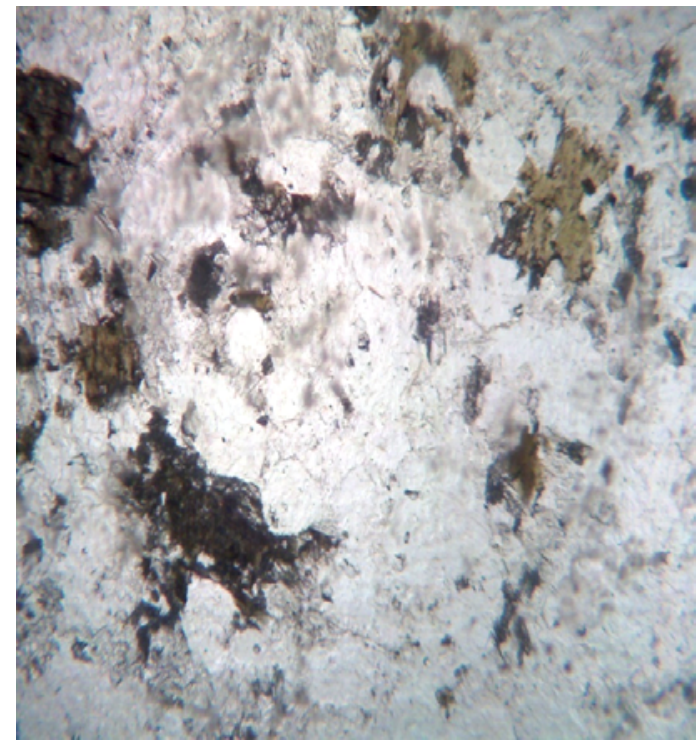

(b)

Table 1: Mineral optical properties and visual estimation in percentage of Plates 1a and 1b

\begin{tabular}{|c|c|c|c|c|c|c|c|}
\hline Mineral & Colour in PPL & Colour in XP & $\begin{array}{l}\text { Extinction } \\
\text { angle }\end{array}$ & $\begin{array}{l}\text { Diagnostic } \\
\text { feature }\end{array}$ & Twinning & $\begin{array}{l}\% \text { in Thin } \\
\text { Section }\end{array}$ & Rock name \\
\hline Quartz $\left(\mathrm{SiO}_{2}\right)$ & Colourless & grey to cream & Parallel & $\begin{array}{l}\text { Irregular with no } \\
\text { cleavage }\end{array}$ & Absent & $30 \%$ & \\
\hline $\begin{array}{l}\text { Plagioclase } \\
\left(\mathrm{NaAlSi}_{3} \mathrm{O}_{8}-\right.\end{array}$ & Colourless & yellow & About $45^{0}$ & $\begin{array}{l}\text { Granulose } \\
\text { structure }\end{array}$ & Multiple & $15 \%$ & \\
\hline $\begin{array}{l}\left.\mathrm{CaAl}_{2} \mathrm{Si}_{2} \mathrm{O}_{8}\right) \\
\text { Hornblende }\end{array}$ & Brown & Blue & $30^{\circ}$ & $\begin{array}{l}\text { Show } \\
\text { pleochroism }\end{array}$ & Simple & $5 \%$ & $\begin{array}{l}\text { Porphyritic } \\
\text { Granite }\end{array}$ \\
\hline $\begin{array}{l}\text { Orthoclase } \\
\left(\mathrm{KNaAlSi}_{3} \mathrm{O}_{8}\right)\end{array}$ & Colourless & White & About $15^{0}$ & Interlocking & $\begin{array}{l}\text { Cross - } \\
\text { Hatch }\end{array}$ & $40 \%$ & \\
\hline Muscovite & Colourless & Green & Parallel & $\begin{array}{l}\text { Elongated } \\
\text { structure with } \\
\text { wavy colour }\end{array}$ & Absent & $10 \%$ & \\
\hline
\end{tabular}


Plate 2 Photomicrograph of granodiorite (a) under crossed polar and (b) under plane polar (Mg.10X)

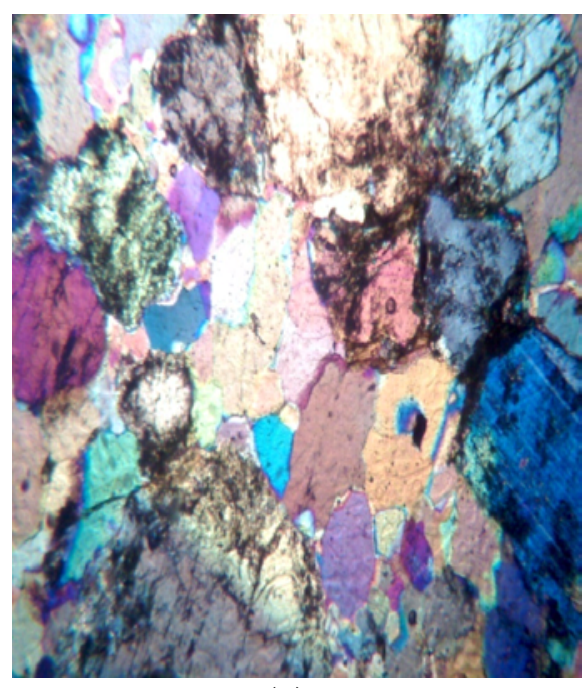

(a)

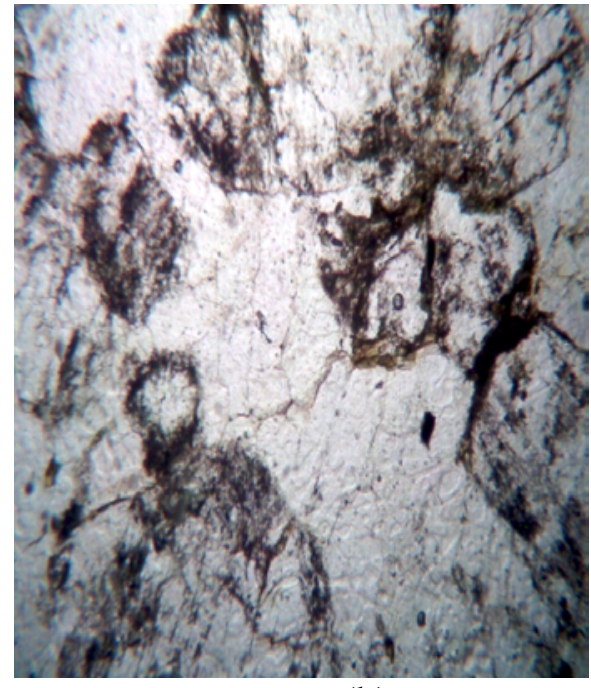

(b)

Table 2: Mineral optical properties and visual estimation in percentage of Plate $2 \mathrm{a}$ and $2 \mathrm{~b}$

\begin{tabular}{|c|c|c|c|c|c|c|c|}
\hline Mineral & Colour in PPL & Colour in XP & $\begin{array}{l}\text { Extinction } \\
\text { angle }\end{array}$ & $\begin{array}{l}\text { Diagnostic } \\
\text { feature }\end{array}$ & Twinning & $\begin{array}{l}\% \text { in Thin } \\
\text { Section }\end{array}$ & Rock name \\
\hline Quartz $\left(\mathrm{SiO}_{2}\right)$ & Colourless & $\begin{array}{l}\text { First order } \\
\text { white to grey } \\
\text { to cream }\end{array}$ & Parallel & $\begin{array}{l}\text { Lack of } \\
\text { cleavage and } \\
\text { alteration, } \\
\text { irregular grains }\end{array}$ & None & $25 \%$ & \\
\hline $\begin{array}{l}\text { Plagioclase } \\
\left(\mathrm{NaAlSi}_{3} \mathrm{O}_{8}-\right. \\
\left.\mathrm{CaAl}_{2} \mathrm{Si}_{2} \mathrm{O}_{8}\right)\end{array}$ & Colourless & light yellow & $40^{0}-45^{0}$ & $\begin{array}{l}\text { Multiple } \\
\text { twinning }\end{array}$ & $\begin{array}{l}\text { Multiple } \\
\text { twins }\end{array}$ & $35 \%$ & Granodiorite. \\
\hline Hornblende & Green - blue & $\begin{array}{l}\text { Ink blue - } \\
\text { black }\end{array}$ & $\begin{array}{l}30^{0} \text { to long } \\
\text { cleavage }\end{array}$ & $\begin{array}{l}\text { Poikilitic plates } \\
\text { rather than } \\
\text { euhedral crystals }\end{array}$ & Simple & $20 \%$ & \\
\hline $\begin{array}{l}\text { K - Feldspar } \\
\text { (Microcline) }\end{array}$ & Colourless & Light blue & Oblique & $\begin{array}{l}\text { Cross-Hatch } \\
\text { twinning }\end{array}$ & $\begin{array}{l}\text { Cross - } \\
\text { Hatch }\end{array}$ & $10 \%$ & \\
\hline Muscovite & Colourless & $\begin{array}{l}\text { High second } \\
\text { order bright } \\
\text { pink \& green }\end{array}$ & Parallel & $\begin{array}{l}\text { Perfect cleavage } \\
\text { high } \\
\text { polarization } \\
\text { colours }\end{array}$ & None & $5 \%$ & \\
\hline Biotite & Brown & $\begin{array}{l}\text { High second } \\
\text { order bright } \\
\text { pink }\end{array}$ & $\begin{array}{l}\text { Straight to } 0 \\
\text { (parallel) }\end{array}$ & $\begin{array}{l}\text { Perfect cleavage } \\
\text { high } \\
\text { polarization } \\
\text { colours }\end{array}$ & None & $5 \%$ & \\
\hline
\end{tabular}


Plate 3Photomicrograph of granite (a) under crossed polar and (b) under plane polar (Mg.10X)
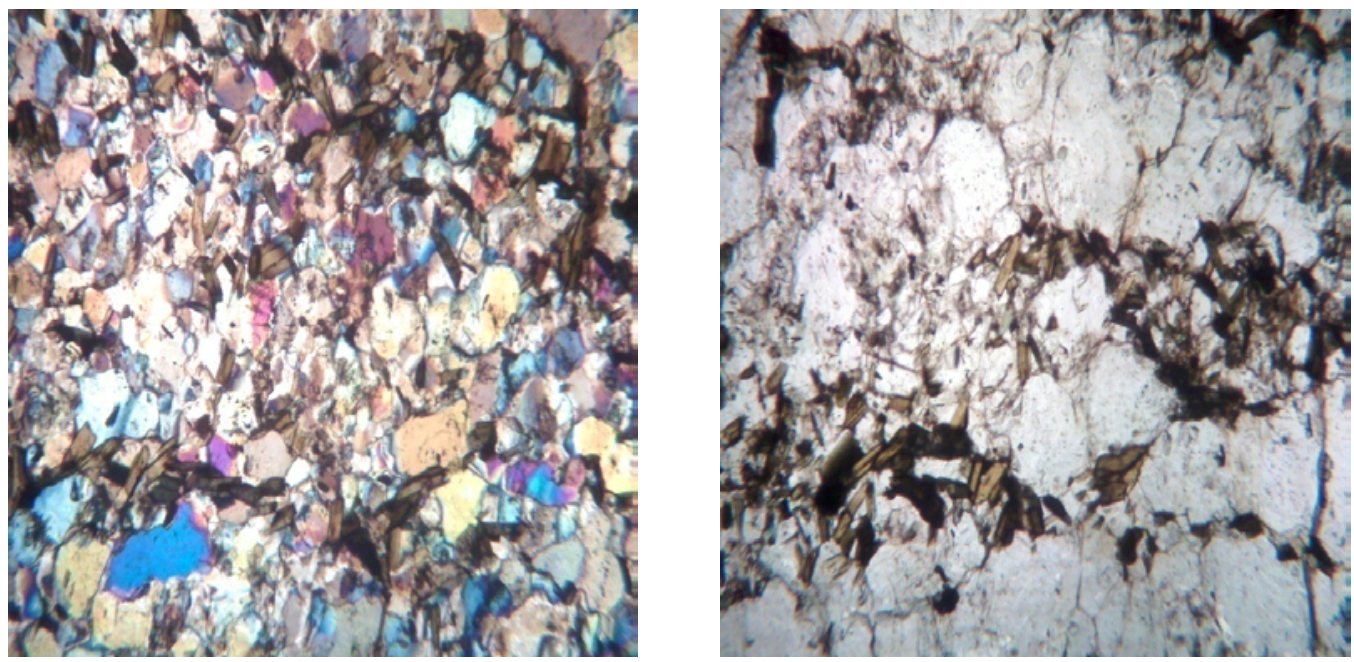

Table 3: Mineral optical properties and visual estimation in percentage of Plate $3 \mathrm{a}$ and $3 \mathrm{~b}$

\begin{tabular}{|c|c|c|c|c|c|c|c|}
\hline Mineral & Colour in PPL & Colour in XP & $\begin{array}{l}\text { Extinction } \\
\text { angle }\end{array}$ & $\begin{array}{l}\text { Diagnostic } \\
\text { feature }\end{array}$ & Twinning & $\begin{array}{l}\% \text { in Thin } \\
\text { Section }\end{array}$ & Rock name \\
\hline Quartz $\left(\mathrm{SiO}_{2}\right)$ & Colourless & grey to cream & Parallel & $\begin{array}{l}\text { Irregular with no } \\
\text { cleavage }\end{array}$ & Absent & $30 \%$ & \\
\hline $\begin{array}{l}\text { Plagioclase } \\
\left(\mathrm{NaAlSi}_{3} \mathrm{O}_{8}-\right. \\
\left.\mathrm{CaAl}_{2} \mathrm{Si}_{2} \mathrm{O}_{8}\right)\end{array}$ & Colourless & yellow & About $45^{0}$ & $\begin{array}{l}\text { Granulose } \\
\text { structure }\end{array}$ & Multiple & $15 \%$ & m \\
\hline $\begin{array}{l}\left.\mathrm{CaAl}_{2} \mathrm{SI}_{2} \mathrm{U}_{8}\right) \\
\text { Hornblende }\end{array}$ & Brown & Blue & $30^{\circ}$ & $\begin{array}{l}\text { Show } \\
\text { pleochroism }\end{array}$ & Simple & $5 \%$ & $\begin{array}{l}\text { Grained } \\
\text { Granite }\end{array}$ \\
\hline Microcline & Colourless & White & About $15^{0}$ & Interlocking & $\begin{array}{l}\text { Cross - } \\
\text { Hatch }\end{array}$ & $40 \%$ & \\
\hline Biotite & Brown & Red & Parallel & $\begin{array}{l}\text { Elongated } \\
\text { structure with } \\
\text { wavy colour }\end{array}$ & Absent & $10 \%$ & \\
\hline
\end{tabular}


Table 4: Mineralogical comparison of the Tegina granite with Minna granite

\begin{tabular}{|c|c|c|}
\hline Mineral & $\begin{array}{c}\times \text { Madaka } \\
\% / 0 \\
\end{array}$ & 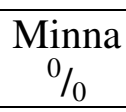 \\
\hline Quartz & 33 & 25 \\
\hline Plagioclase & 43 & 35 \\
\hline Microcline & 07 & 10 \\
\hline Biotite & 11 & 8 \\
\hline Muscovite & - & 2 \\
\hline \multicolumn{3}{|c|}{$\times$ Madaka granite( Trsuwell et. al, 1963) } \\
\hline \multicolumn{3}{|c|}{ Table 5: Mineralogical comparison of the Tegina granodiorite with Minna granodiorite } \\
\hline Mineral & $\begin{array}{c}\times \text { Tegina } \\
0 \%\end{array}$ & $\begin{array}{c}\text { Minna } \\
\%\end{array}$ \\
\hline Quartz & 28 & 30 \\
\hline Plagioclase & 25 & 15 \\
\hline Microcline & 36 & 40 \\
\hline Biotite & 6 & 10 \\
\hline Hornblend & - & 5 \\
\hline
\end{tabular}

